\title{
Nuclear Factor-Kappa B and Other Oxidative Stress Biomarkers in Serum of Autistic Children
}

\author{
Omar M. E. Abdel-Salam¹, Eman R. Youness ${ }^{2}$, Nadia A. Mohammed², \\ Walaa A. Abu Elhamed ${ }^{3}$ \\ ${ }^{1}$ Department of Toxicology and Narcotics, National Research Centre, Cairo, Egypt \\ ${ }^{2}$ Department of Medical Biochemistry, National Research Centre, Cairo, Egypt \\ ${ }^{3}$ Department of Pediatrics, Faculty of Medicine, Cairo University, Cairo, Egypt \\ Email: omasalam@hotmail.com
}

Received 26 January 2015; accepted 11 February 2015; published 16 February 2015

Copyright (C) 2015 by authors and Scientific Research Publishing Inc.

This work is licensed under the Creative Commons Attribution International License (CC BY).

http://creativecommons.org/licenses/by/4.0/

\section{(c) (i) Open Access}

\section{Abstract}

The aim of the present study was to investigate the status of oxidative stress in the serum of children affected with autism spectrum disorder. Twenty autistic children aged 3 to 12 years, were gender and age-matched with 20 typically developing children. Changes in the levels of the redox-sensing transcription factor nuclear factor-kappa B (NF- $\kappa$ B) was measured in serum of autistic children and controls. Other oxidative stress biomarkers such as malondialdehyde, reduced glutathione, total antioxidant capacity, catalase activity, and paraoxonase 1 activity were determined in serum as well. Significant increase was observed in serum NF- $\mathrm{B}$ of autistic children compared to that in controls (by $\mathbf{1 3 8 . 6 \%}$ ). There was also marked increase in malondialdehyde level by $87.3 \%$ in autistic patients. Meanwhile, there were significant decreases in reduced glutathione (by 24\%), catalase activity (by 40.8\%), paraoxonase 1 activity (by 36.6\%), and total antioxidant capacity (by $36.5 \%$ ) compared to the control group. These data clearly demonstrate increased oxidative stress in serum of autistic children and suggest that the NF- $\kappa \mathrm{B}$ signaling pathway is activated in autism, possibly due to increased oxidative burden.

\section{Keywords}

Autism Spectrum Disorder, Oxidative Stress, Redox-Sensing Transcription Factor

\section{Introduction}

Autism spectrum disorder is a pervasive neurodevelopmental disorder that affects children and is characterized 
by difficulties in communication and social interaction, defects in attention, cognitive, and learning abilities and by repetitive and stereotypic behaviors [1]. More males are affected than females with a ratio of 4:1 [2] [3]. The exact cause of autism is still not known. Increased oxidative stress [4], impaired mitochondrial function [5], immune dysregulation [6], and increased brain inflammation [7], are among pathogenetic processes implicated. Both genetic [8], and environmental factors e.g., diet, bacterial or viral infection, xenobiotics [9]-[11] have been suggested to have a role in this disorder.

Oxidative stress and neuroinflammation are the two major processes involved in neurodevelopmental and neurodegenerative disorders [12] [13]. Oxidative stress ensues when the cell's antioxidant mechansims are overwhelmed by excessive free radicals. With its relatively low content of antioxidants, the high content of polyunsaturated fatty acids and the presence of redox active metals $\left(\mathrm{Cu}^{++}, \mathrm{Fe}^{+++}\right)$, the brain tissue seems highly vulnerable to free radical attack [12]. Indeed oxidative stress is frequently encountered in several central nervous system diseases including Parkinson's disease, Alzheimer's disease, amyotrophic lateral sclerosis, multiple sclerosis, and schizophrenia [12] [14]-[16]. Several enzymatic and non-enzymatic antioxidants act to maintain the redox status of the cell [2] [17]. In brain, glutathione is the most abundant antioxidant in the cell and a decrease in this thiol is a feature in several neurodenenerative diseases. Glutathione serves as a reducing agent and as antioxidant. It exists in both a reduced state as well as an oxidized form, and the relative amounts of each determine the redox status of the cell [18]-[20].

Nuclear factor $\kappa \mathrm{B}(\mathrm{NF}-\kappa \mathrm{B})$ is a protein transcription factor that functions to enhance the transcription of a number of genes, involved in the control of the cellular immune and inflammatory response [21]. NF- $\kappa \mathrm{B}$ was first described in 1986 as a nuclear factor that binds to the enhancer element of the immunoglobulin kappa lightchain of activated B cells [22]. The NF- $\kappa \mathrm{B}$ family of transcription factors comprise five members designated as p65 (RelA), RelB, c-Rel, NF- $\kappa$ B1 and NF- $\kappa$ B2 and that in quiescent cells bound to inhibitory molecules of the $\mathrm{I} \kappa \mathrm{B}$ family of proteins. NF- $\kappa \mathrm{B}$ is kept in the cytoplasm inactivated by $\mathrm{I} \kappa \mathrm{B}$. Once activated by release from the $\mathrm{I} \kappa \mathrm{B} / \mathrm{NF}-\kappa \mathrm{B}$ complex, NF- $\kappa \mathrm{B}$ translocates to the nucleus and acts to orchestrate the transcription of enzymes e.g., inducible nitric oxide synthase (iNOS) and cycloxygenase-2 (COX-2), cytokines e.g., interleukin $1 \beta$ (IL-1 $\beta$ ), IL-2, 6, 8, tumour necrosis factor-alpha (TNF- $\alpha$ ), interferon, growth factors, cell adhesion molecules, immunoreceptors, monocytes chemoattractant protein-1 (MCP-1) and stress proteins [21] [23]-[25].

The aim of the present study was to investigate the antioxidant status in children affected with autism spectrum disorder by measuring the changes in the levels of the redox transcription factor NF- $\kappa \mathrm{B}$ in serum autistic children and controls. Other indices of oxidative stress, namely serum malondialdehyde as an index of damage to macromolecules (lipid peroxidation) [26], reduced glutathione, catalase as well as total antioxidant capacity were also measured. We in addition determined the activity of paraoxonase 1 enzyme, a detoxifying enzyme involved in the hydrolysis of organophosphate and many xenobiotics [27] and which has been shown of significance in neurological diseases [28].

\section{Patients and Methods}

\subsection{Patients Selection}

This cross sectional case-control study was conducted on 20 autistic children and adolescents diagnosed according to the 4th edition of Diagnostic and Statistical Manual of Mental Disorders (DSM IV) [1] that was done by a child psychiatrist. Patients were recruited from Pediatric Psychiatry Clinic, Children's hospital, Faculty of Medicine, Cairo University, Egypt during the period from 2013-2014. They were 15 males and 5 females. Their ages ranged between 3 and 12 years with a mean age $5.67 \pm 0.59$ years. None of the patients had underlying conditions apart from autism (syndromic causes, chromosomal or metabolic abnormalities). Autistic patients were studied in comparison to 20 healthy age-, sex- and pubertal stage-matched children and adolescents serving as controls. The latter had no clinical findings suggesting neither neuropsychiatric manifestations nor any organic health problems and medications affecting our result. An informed written consent of participation in the study was signed by the parents or legal guardians of the studied subjects. This study was approved by the Bioethical Research Committee, Faculty of Medicine, Cairo University hospitals, Egypt.

\subsection{Laboratory Investigations}

\subsubsection{Quantification of NF- $\kappa$ B}

NF- $\kappa$ B was measured in serum using commercially available human NF- $\kappa$ B ELISA kit (Glory Science Co., Ltd., 
Del Rio, TX, USA) according to manufacture instructions. The kit uses a double antibody sandwich enzymelinked immunosorbent assay to assay the level of NF- $\kappa$ B. The detection range of the kit is: $100 \mathrm{U} / \mathrm{L}-2000 \mathrm{U} / \mathrm{L}$.

\subsubsection{Determination of Lipid Peroxidation}

Lipid peroxidation was assayed in serum by measuring the thiobarbituric-acid-reacting substances in tissue homogenates, as previously described by Ruiz-Larrea et al. [29] in which the thiobarbituric acid reactive substances react with thiobarbituric acid to produce a red colored complex having peak absorbance at $532 \mathrm{~nm}$ (using UV-VI8 Recording Spectrophotometer (Shimadzu Corporation, Australia)).

\subsubsection{Determination of Reduced Glutathione}

Reduced glutathione was determined according to the method of Beutler et al. [30]. The procedure is based on the reduction of Ellman's reagent by-SH groups of GSH to form 2-nitro-s-mercaptobenzoic acid, which is intense yellow in colour and determined spectrophotometrically at $412 \mathrm{~nm}$.

\subsubsection{Determination of Total Antioxidant Capacity}

Total serum antioxidant activity was determined by the reaction of antioxidants in the sample with a defined amount of exogenously provide hydrogen peroxide $\left(\mathrm{H}_{2} \mathrm{O}_{2}\right)$. The antioxidants eliminate a certain amount of the provided $\mathrm{H}_{2} \mathrm{O}_{2}$. The residual $\mathrm{H}_{2} \mathrm{O}_{2}$ is determined colorimetrically by an enzymatic reaction which involves the conversion of 3, 5, dichloro-2-hydroxy benzensulphate to a colored product [31].

\subsubsection{Determination of Catalase Activity}

Catalase activity in brain supernatants was determined spectrophotometrically at $510 \mathrm{~nm}$ using a commercially available kit (Biodiagnostics, Cairo, Egypt). Catalase reacts with a known quantity of $\mathrm{H}_{2} \mathrm{O}_{2}$. The reaction is stopped after exactly one minute with catalase inhibitor. In the presence of peroxidase, remaining $\mathrm{H}_{2} \mathrm{O}_{2}$ reacts with 3,5-dichloro-2-hydroxybenzene to form a chromophore with a color intensity inversely proportional to the amount of catalase in the original sample [32].

\subsubsection{Determination of Paraoxonase 1 Activity}

Paraoxonase 1 activity was determined spectrophotometrically using phenylacetate as a substrate. Aryl esterase/ paraoxonase catalyze cleavage of phenyl acetate into phenol that is measured at wavelength $270 \mathrm{~nm}$ at $25^{\circ} \mathrm{C}$. The working reagent consisted of $20 \mathrm{mM}$ Tris/HCl buffer, $\mathrm{pH}$ 8.0, containing $1 \mathrm{mM} \mathrm{CaCl}_{2}$ and $4 \mathrm{mM}$ phenyl acetate as the substrate. Samples diluted 1:3 in buffer are added and the change in absorbance is recorded following a $20 \mathrm{sec}$ lag time. Absorbance at $270 \mathrm{~nm}$ was taken every $15 \mathrm{~s}$ for $120 \mathrm{~s}$. One unit of arylesterase activity is equal to $1 \mu \mathrm{M}$ of phenol formed per minute. The activity is expressed in $\mathrm{kU} / \mathrm{L}$, based on the extinction coefficient of phenol of $1310 \mathrm{M}^{-1} \cdot \mathrm{cm}^{-1}$ at $270 \mathrm{~nm}, \mathrm{pH} 8.0$, and $25^{\circ} \mathrm{C}$. Blank samples containing water are used to correct for the spontaneous hydrolysis of phenylacetate [33] [34].

\section{Statistical Analysis}

Data are expressed as mean \pm SEM. Statistical analysis of the data was analyzed by Student't test, using SPSS software (SAS Institute Inc., Cary, NC). A probability value of less than 0.05 was considered statistically significant.

\section{Results}

Serum NF- $\kappa$ B concentrations were significantly higher by $138.6 \%(\mathrm{P}<0.001)$ in patients with autism $(322.52 \pm$ 18.2 U/L; range 195 - 610) compared with the control group (mean $135.14 \pm 11.3 \mathrm{U} / \mathrm{L}$; range 101.1 - 167.4) (Figure 1).

In autistic children, serum malondialdehyde increased by $87.3 \%$ from a mean of $57.6 \pm 3.2 \mu \mathrm{mol} / \mathrm{L}$ (range, $44.3-66.30 \mu \mathrm{mol} / \mathrm{L}$ ) in control group to $107.9 \pm 6.1 \mu \mathrm{mol} / \mathrm{L}$ (range, $73.67-152.0 \mu \mathrm{mol} / \mathrm{L})(\mathrm{P}<0.001)$ in children with autistic disorder (Figure 2). Meanwhile, there was a significant decrease in reduced glutathione in serum in children with autism by $24 \%(\mathrm{P}<0.001)$ from control values of $7.5 \pm 0.29 \mu \mathrm{mol} / \mathrm{L}$ (range $7.13-8.5)$ in the control group to $5.71 \pm 0.21 \mu \mathrm{mol} / \mathrm{L}$ (range 5.1 - 6.41) (Figure 3).

Catalase activity in serum decreased by $40.8 \%$ in autistic children from control values of $21.01 \pm 1.84 \mathrm{U} / \mathrm{mL}$ 


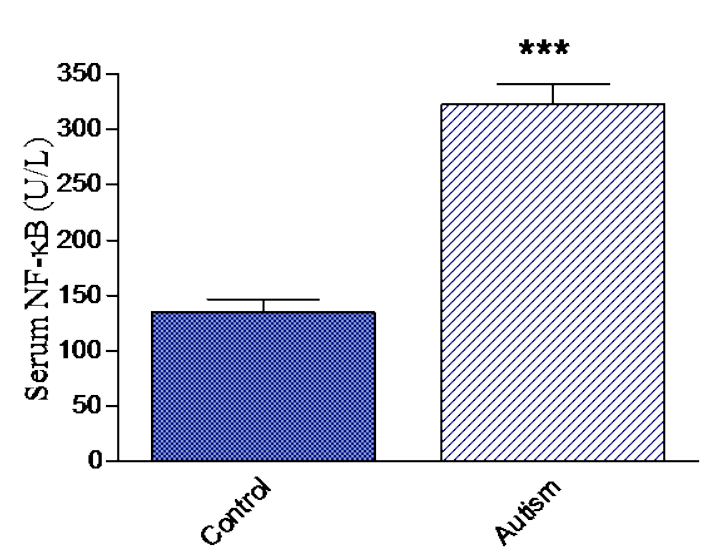

Figure 1. Nuclear factor-kappa B (NF- $\kappa$ B) in serum of autistic children and healthy controls. ${ }^{* * *} \mathrm{P}<0.001$ vs. control.

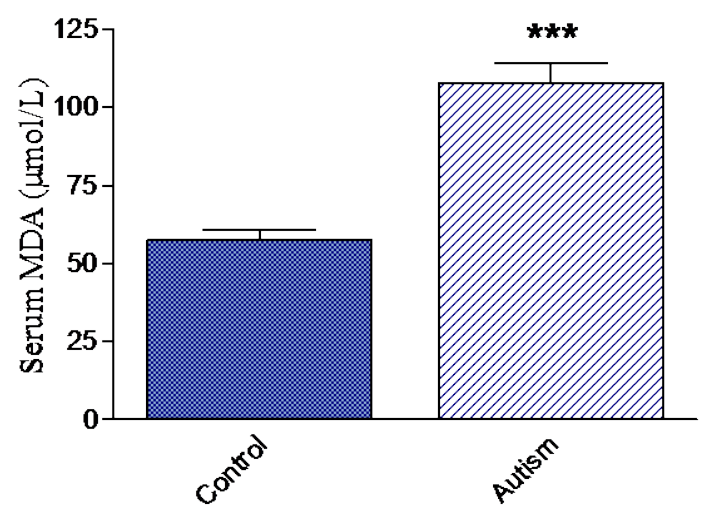

Figure 2. Serum malondialdehyde levels in children with autism and healthy subjects. ${ }^{* * *} \mathrm{P}<0.001$ vs. control.

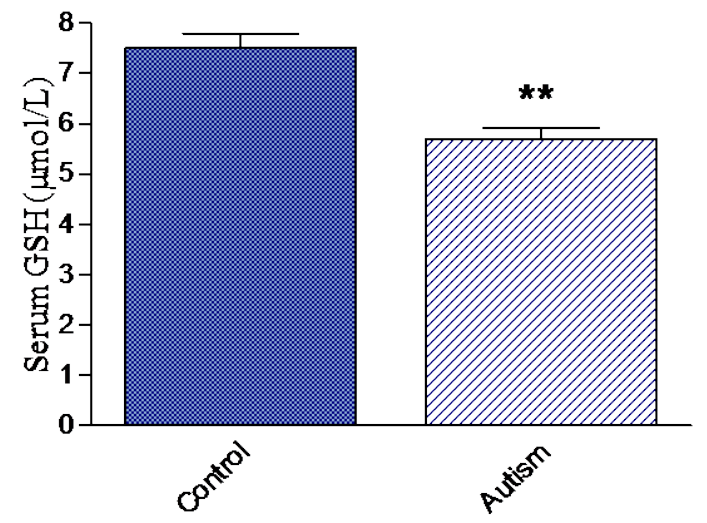

Figure 3. Serum reduced glutathione levels in children with autism and healthy subjects. ${ }^{* *} \mathrm{P}<0.01$ vs. control.

(range 17.81 - 30.57) in the control group to $12.44 \pm 1.07 \mathrm{U} / \mathrm{mL}$ (range 14.61 - 4.71) (Figure 4). In children with autistic disorder, serum total antioxidant capacity also decreased by $36.5 \%(\mathrm{P}<0.01)$ from a mean of $3.18 \pm 0.29$ 
$\mu \mathrm{mol} / \mathrm{L}$ (range, $1.6-4.4 \mu \mathrm{mol} / \mathrm{L}$ ) in control group to $2.02 \pm 0.16 \mu \mathrm{mol} / \mathrm{L}$ (range, $1.10-4.3 \mu \mathrm{mol} / \mathrm{L}$ ) in those with autism (Figure 5). Serum paraoxonase 1 activity also significantly decreased by $36.6 \%(\mathrm{P}<0.01)$ from control values of $297.42 \pm 21.0 \mathrm{kU} / \mathrm{L}$ (range 229.1 - 335) in the control group to $188.58 \pm 15.9 \mathrm{kU} / \mathrm{L}$ (range 137.3 229.2) in autistic children (Figure 6).

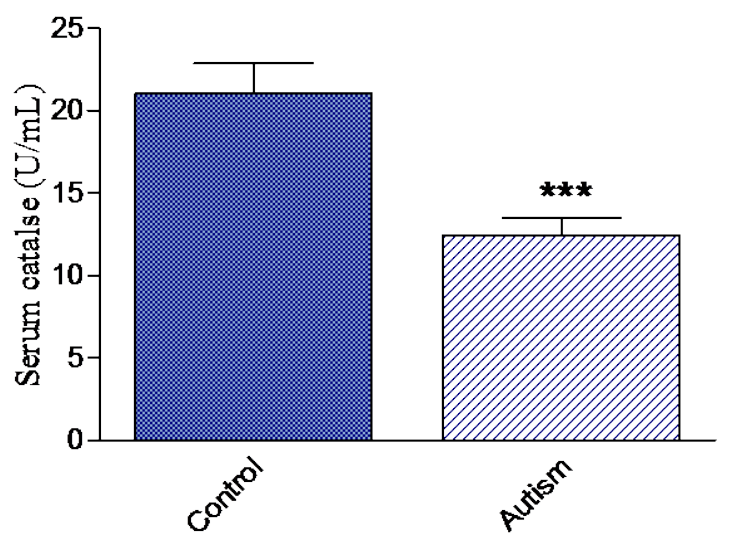

Figure 4. Catalase activity in serum of autistic children and healthy controls. ${ }^{* * *} \mathrm{P}<0.001$ vs. control.

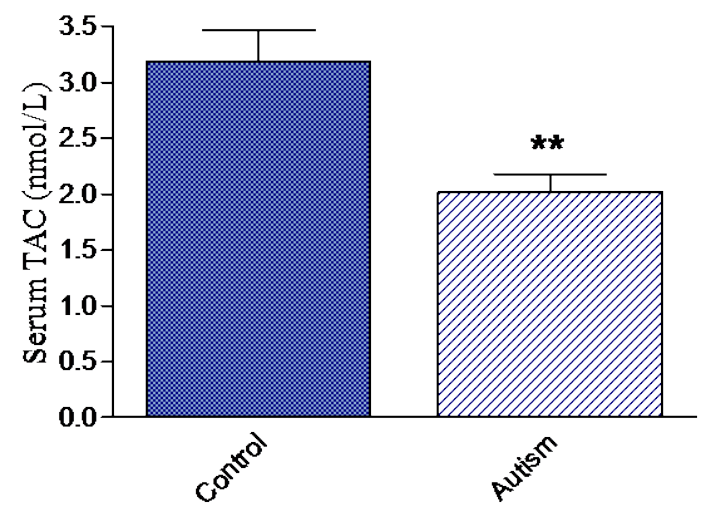

Figure 5. Total antioxidant capacity in serum of children with autism and healthy subjects. ${ }^{* *} \mathrm{P}<0.01$ vs. control.

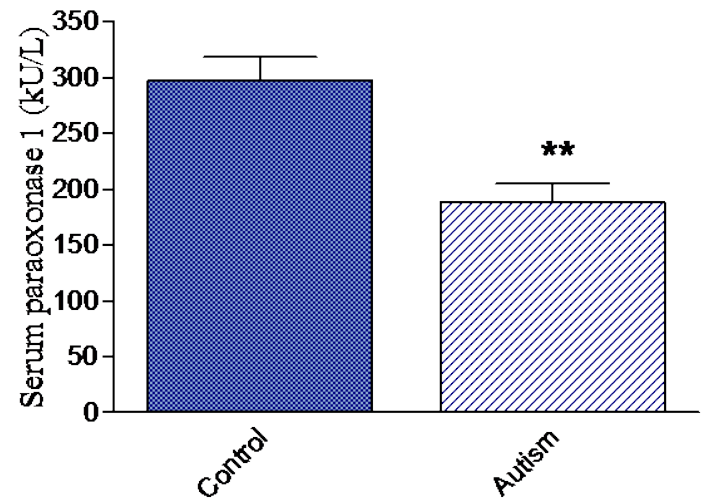

Figure 6. Paraoxonase 1 activity in serum of children with autism and healthy subjects. ${ }^{* *} \mathrm{P}<0.01$ vs. control. 


\section{Discussion}

The findings in the present study provided the evidence that the redox sensitive transcription factor NF- $\kappa \mathrm{B}$ is increased in serum of children with autism spectrum disorder. This transcription factor has been shown to be an important regulator of the expression of many cytokines, chemokines, cell adhesion molecules and acute phase proteins and enzyme genes involved in the cellular inflammatory and immune response [21]-[25]. NF- $\kappa \mathrm{B}$ is a sensor of oxidative stress in that its activity is regulated by the levels of intracellular reactive oxygen metabolites and activation can be inhibited by a variety of antioxidants and by overexpression of antioxidant enzymes [21]. Measurement of NF- $\kappa \mathrm{B}$ activity can thus be used as a functional biomarker of oxidative stress [35]. I $\kappa \mathrm{B} \alpha / \mathrm{NF}-\kappa \mathrm{B}$ pathway is also involved in regulating redox-dependent regulation of cytokines [24].

There is evidence to suggest the involvement of the NF- $\kappa \mathrm{B}$ signaling pathway in the inflammatory process in the autistic brain. Significant increase in NF- $\kappa$ B DNA binding activity in blood samples from children with autistic disorder has also been reported using electrophoretic mobility shift assay [36]. Studies indicated increased $\mathrm{NF}-\kappa \mathrm{B}$ activity in brain of autistic individuals. In human post-mortem samples of orbitofrontal cortex tissue, concentrations of NF- $\kappa$ B were elevated, especially in activated microglia. Neurons, astrocytes, and microglia all demonstrated increased extra nuclear and nuclear translocated NF- $\kappa \mathrm{B}$ p65 expression [37]. Malik et al. [38], however, suggested that the NF- $\kappa \mathrm{B}$ signaling pathway is not disregulated in the brain of autistic subjects. In their study, the level of IKK $\alpha$ kinase, which phosphorylates the inhibitory subunit $\mathrm{I} \kappa \mathrm{B} \alpha$ (and thus the dissociation of $\mathrm{NF}-\kappa \mathrm{B}$ from the $\mathrm{I} \kappa \mathrm{B} / \mathrm{NF}-\kappa \mathrm{B}$ complex and its translocation to the nucleus) was significantly increased in the cerebellum of autistic subjects but the expression and phosphorylation of $\mathrm{I} \kappa \mathrm{B} \alpha$ were not altered.

In the cell both antioxidant enzymatic machinery and non-enzymatic antioxidant molecules act to neutralize excess free radicals and maintain the intracellular redox balance. These are the cytosolic copper-zinc superoxide dismutase and the mitochondrial manganese superoxide dismutase, catalase, glutathione peroxidase, glutathione reductase, and non-enzymatic antioxidants e.g., thiols, ascorbate, tocopherols, carotenoids, and uric acid [17] [39] [40]. "Oxidative stress" is the term used to describe the state in which there is an imbalance between prooxidants and antioxidants in favor of the prooxidants. The result is damage to cellular macromolecules (proteins, lipids, DNA) and disruption of redox signaling and cell control [40] [41]. Increased levels of oxidative damage, however, does not necessarily indicate increased oxidative stress (i.e., increased free radical generation), but can be encountered when antioxidant mechanisms are reduced and become inadequate to control the levels of reactive oxygen species [41]-[43]. The present study demonstrated increased oxidative stress, i.e., increased serum concentrations of the lipid peroxidation product malondialdehyde, a surrogate of increased free radical attack on membrane lipids. Moreover the present study showed reduced concentrations of the antioxidant molecule reduced glutathione and the antioxidant enzyme catalase in autistic children. The tripeptide glutathione ( $\gamma$-glutamylcysteinylglycine) is the most abundant nonprotein thiol in cells [20]. In the brain tissue where there is paucity of antioxidant mechanisms, glutathione plays an important role in preventing oxidative stress and maintaining the redox equilibrium in the cell. Glutathione participates either by directly scavenging reactive oxygen and nitrogen intermediates (e.g., superoxide, nitric oxide, hydroxyl radical, and peroxynitrite) or by acting as a co-factor for glutathione peroxidase and glutathione reductase [44] [45]. In autistic children there is evidence for glutathione redox imbalance both in the peripheral blood and brain. Thus, decreased total glutathione content in peripheral blood from autistic patients has been reported [46]. Significantly increased non-protein-bound iron (a pro-oxidant factor) has also been found in plasma of autistic children. Erythrocyte glutathione decreased and 4-hydroxynonenal protein adducts increased in erythrocyte membranes and in plasma, indicting lipid peroxidation-induced protein damage [47]. Moreover, lymphoblastoid cells derived from autistic children exhibited decreased reduced glutathione/oxidized glutathione redox ratio and increased percentage of oxidized glutathione in both cytosol and mitochondria [48]. Significant decreases in reduced glutathione and increases in oxidized glutathione were detected in the cerebellum and temporal cortex from subjects with autism [49]. It has also been shown that the activity of glutathione peroxidase and glutathione-S-transferase enzymes as well as glutamate cysteine ligase, the rate limiting enzyme for glutathione synthesis decreased in cerebellar tissue of autistic patients [50]. Glutathione depletion plays important role in several neuropathological disease states e.g., Parkinson's disease, schizophrenia, and major depression and replenishing cellular glutathione have been advocated as a therapeutic approach in these conditions [19] [51] [52]. Increasing glutathione levels through nasal or intravenously given glutathione or via its oral precursor $\mathrm{N}$-acetylcysteine might also prove of value in autistic individuals. 
Methods for measuring total antioxidant capacity were developed as simple, single and quick tests for evaluating the oxidative status in plasma and biological tissues. Instead of measuring the concentrations of individual antioxidants, the total antioxidant capacity is largely thought to reflect the overall capacity of antioxidants and antioxidant enzymes in a biological sample [53]-[55]. Total antioxidant capacity decreases in patients with CRF [54], HIV patients [56], during chemotherapy for malignancy [57] [58]. In this study, reduced total antioxidant capacity was demonstrated in sera of autistic children, suggesting decreased endogenous antioxidants.

Paraoxonases are a group of detoxifying enzymes which comprises three isoforms: PON1, PON2 and PON3. Paraoxonases hydrolyze the toxic oxon metabolites of several organophosphate insecticides (e.g., chlorpyrifos oxon, diazoxon), the nerve agents such as sarin, soman as well as many different substrates and xenobiotics [25]. The paraoxonase family of enzymes has recently received attention for their postulated role in several neurological disorders [26]. The paraoxonase 1 (PON1) enzyme is synthesized in the liver and released into circulation where it binds with high density lipoproteins and protects low density lipoproteins and cellular membranes from oxidative damage [33] [59] [60]. It possesses organophosphatase, arylesterase and lactonase activities [60] and exerts peroxidase activities that may be important in neurodegenerative disorders associated with oxidative stress [26]. Plasma levels of this enzyme decreases in neurological diseases such as multiple sclerosis during relapse [61], major depression [62], patients with Alzheimer's disease or other dementias [63] [64]. In the present study, we observed significantly decreased arylesterase activity in serum of autistic children. Gaita et al. [65] reported significantly decreased serum PON 1 arylesterase, but not diazoxonase activity, in patients with autism compared to controls and first-degree relatives. A functional rather than quantitative change in protein amounts accounting for the reduction in PON 1 activity has been suggested. Serum PON1 (and PON3) is inactivated under oxidative stress [66] [67] and it is possible that the decreased arylesterase activity of the enzyme observed in neurological diseases and in autism is due to the increased level of oxidative stress in these disease conditions.

In summary, we demonstrated increased lipid peroxidation and decreased antioxidant mechanisms in serum of children with the autistic disorder compared to healthy controls. The increased oxidative stress is likely to account for the activation of the NF- $\kappa$ B pathway in these patients.

\section{References}

[1] American Psychiatric Association (1994) Diagnostic and Statistical Manual of Mental Disorders. DSM-IV. 4th Edition, American Psychiatric Association, Washington DC.

[2] Baird, G., Cass, H. and Slonims, V. (2003) Diagnosis of Autism. BMJ, 327, 488-493. http://dx.doi.org/10.1136/bmj.327.7413.488

[3] Fombonne, E., Zakarian, R., Bennett, A., Meng, L. and McLean-Heywood, D. (2006) Pervasive Developmental Disorders in Montreal, Quebec, Canada: Prevalence and Links with Immunizations. Pediatrics, 118, e139-e150. http://dx.doi.org/10.1542/peds.2005-2993

[4] Napoli, E., Wong, S. and Giulivi, C. (2013) Evidence of Reactive Oxygen Species-Mediated Damage to Mitochondrial DNA in Children with Typical Autism. Molecular Autism, 4, 2. http://dx.doi.org/10.1186/2040-2392-4-2

[5] Gargus, J.J. and Imtiaz, F. (2008) Mitochondrial Energy-Deficient Endophenotype in Autism. American Journal of Biochemistry and Biotechnology. Special Issue on Autism Spectrum Disorders, 4, 198-207.

[6] Cohly, H.H. and Panja, A. (2005) Immunological Findings in Autism. International Review of Neurobiology, 71, 317-341. http://dx.doi.org/10.1016/S0074-7742(05)71013-8

[7] Theoharides, T.C., Asadi, S. and Patel, A.B. (2013) Focal Brain Inflammation and Autism. Journal of Neuroinflammation, 10, 46. http://dx.doi.org/10.1186/1742-2094-10-46

[8] De Rubeis, S., He, X., Goldberg, A.P., Poultney, C.S., Samocha, K., Ercument Cicek, A., Kou, Y., Liu, L. et al. (2014) Synaptic, Transcriptional and Chromatin Genes Disrupted in Autism. Nature, 515, 209-215. http://dx.doi.org/10.1038/nature13772

[9] Edelson, S.B. and Cantor, D.S. (2000) The Neurotoxic Etiology of the Autistic Spectrum Disorder: A Replicative Study. Toxicology and Industrial Health, 16, 239-247. http://dx.doi.org/10.1177/074823370001600604

[10] Vojdani, A., Campbell, A.W., Anyanwu, E., Kashanian, A., Bock, K. and Vojdani, E. (2002) Antibodies to Neuron-Specific Antigens in Children with Autism: Possible Cross Reaction with Encephalitogenic Proteins from Milk, Chlamydia Pneumoniae and Stretoccoccus Group A. Journal of Neuroimmunology, 129, 168-177. http://dx.doi.org/10.1016/S0165-5728(02)00180-7

[11] Vojdani, A., Mumper, E., Granpeesheh, D., Mielke, L., Traver, D., Bock, K., Hirani, K., Neubrander, J., Woeller, K.N., O’Hara, N., Usman, A., Schneider, C., Hebroni, F., Berookhim, J. and McCandless, J. (2008) Low Natural Killer Cell 
Cytotoxic Activity in Autism: The Role of Glutathione, IL-2 and IL-15. Journal of Neuroimmunology, 205, 148-154. http://dx.doi.org/10.1016/j.jneuroim.2008.09.005

[12] Halliwell, B. (2001) Role of Free Radicals in the Neurodegenerative Diseases. Drugs \& Aging, 18, 685-716. http://dx.doi.org/10.2165/00002512-200118090-00004

[13] Hirsch, E.C. and Hunot, S. (2009) Neuroinflammation in Parkinson's Disease: A Target for Neuroprotection? The Lancet Neurology, 8, 382-397. http://dx.doi.org/10.1016/S1474-4422(09)70062-6

[14] Dasuri, K., Zhang, L. and Keller, J.N. (2013) Oxidative Stress, Neurodegeneration, and the Balance of Protein Degradation and Protein Synthesis. Free Radical Biology and Medicine, 62, 170-185.

[15] Yao, J.K. and Reddy, R. (2011) Oxidative Stress in Schizophrenia: Pathogenetic and Therapeutic Implications. Antioxidants \& Redox Signaling, 15, 1999-2002. http://dx.doi.org/10.1089/ars.2010.3646

[16] Haider, L., Fischer, M.T., Frischer, J.M., Bauer, J., Hoftberger, R., Botond, G., Esterbauer, H., Binder, C.J., Witztum, J.L. and Lassmann, H. (2011) Oxidative Damage in Multiple Sclerosis Lesions. Brain, 134, 1914-1924. http://dx.doi.org/10.1093/brain/awr128

[17] Sies, H. (1997) Oxidative Stress: Oxidants and Antioxidants. Experimental Physiology, 82, 291-295. http://dx.doi.org/10.1113/expphysiol.1997.sp004024

[18] Bains, J.S. and Shaw, C.A. (1997) Neurodegenerative Disorders in Humans: The Role of Glutathione in Oxidative Stress-Mediated Neuronal Death. Brain Research Reviews, 25, 335-358. http://dx.doi.org/10.1016/S0165-0173(97)00045-3

[19] Sian, J., Dexter, D.T., Lees, A.J., Daniel, S., Agid, Y., Javoy-Agid, F., Jenner, P. and Marsden, C.D. (1994) Alterations in Glutathione Levels in Parkinson's Disease and Other Neurodegenerative Disorders Affecting Basal Ganglia. Annals of Neurology, 36, 348-355. http://dx.doi.org/10.1002/ana.410360305

[20] Dickinson, D.A. and Forman, H.J. (2002) Cellular Glutathione and Thiols Metabolism. Biochemical Pharmacology, 64, 1019-1026. http://dx.doi.org/10.1016/S0006-2952(02)01172-3

[21] Li, N. and Karin, M. (1999) Is NF- $\kappa$ B the Sensor of Oxidative Stress? The FASEB Journal, 13, 1137-1143.

[22] Sen, R. and Baltimore, D. (1986) Indicibility of $\kappa$ Immunoglobulin Enhancer-Binding Protein NF- $\kappa$ B by a Posttranslational Mechanism. Cell, 47, 921-928. http://dx.doi.org/10.1016/0092-8674(86)90807-X

[23] Christman, J.W., Blackwell, T.S. and Juurlink, B.H.J. (2000) Redox Regulation of Nuclear Factor Kappa B: Therapeutic Potential for Attenuating Inflammatory Responses. Brain Pathology, 10, 153-162. http://dx.doi.org/10.1111/j.1750-3639.2000.tb00252.x

[24] Haddad, J.J. (2002) Redox Regulation of Pro-Inflammatory Cytokines and $\mathrm{I} \kappa \mathrm{B}-\alpha / \mathrm{NF}-\kappa \mathrm{B}$ Nuclear Translocation and Activation. Biochemical and Biophysical Research Communications, 296, 847-856. http://dx.doi.org/10.1016/S0006-291X(02)00947-6

[25] Celec, P. (2004) Nuclear Factor Kappa B-Molecular Biomedicine: The Next Generation. Biomedicine \& Pharmacotherapy, 58, 365-371. http://dx.doi.org/10.1016/j.biopha.2003.12.015

[26] Gutteridge, J.M. (1995) Lipid Peroxidation and Antioxidants as Biomarkers of Tissue Damage. Clinical Chemistry, 41, 1819-1828.

[27] Furlong, C.E. (2008) Paraoxonases: An Historical Perspective. In: Mackness, B., Mackness, M., Aviram, M. and Paragh, G., Eds., The Paraoxonases: Their Role in Disease Development and Xenobiotic Metabolism, Springer, Dordrecht, 3-31. http://dx.doi.org/10.1007/978-1-4020-6561-3_1

[28] Menini, T. and Gugliucci, A. (2014) Paraoxonase 1 in Neurological Disorders. Redox Report, 19, 49-58. http://dx.doi.org/10.1179/1351000213Y.0000000071

[29] Ruiz-Larrea, M.B., Leal, A.M., Liza, M., Lacort, M. and de Groot, H. (1994) Antioxidant Effects of Estradiol and 2-Hydroxyestradiol on Iron-Induced Lipid Peroxidation of Rat Liver Microsomes. Steroids, 59, 383-388. http://dx.doi.org/10.1016/0039-128X(94)90006-X

[30] Beutler, M., Duron, O. and Kelly, B.M. (1963) Improved Method for the Determination of Blood Glutathione. Journal of Laboratory and Clinical Medicine, 61, 882-888.

[31] Koracevic, D., Koracevic, G. and Djordjevic, V. (2001) Method for the Measurement of Antioxidant Activity in Human Fluids. Journal of Clinical Pathology, 54, 356-361. http://dx.doi.org/10.1136/jcp.54.5.356

[32] Aebi, H. (1984) Catalase in Vitro. Methods in Enzymology, 105, 121-126. http://dx.doi.org/10.1016/S0076-6879(84)05016-3

[33] Higashino, K., Takahashi, Y. and Yamamura, Y. (1972) Release of Phenyl Acetate Esterase from Liver Microsomes by Carbon Tetrachloride. Clinica Chimica Acta, 41, 313-320. http://dx.doi.org/10.1016/0009-8981(72)90526-8

[34] Watson, A.D., Berliner, J.A., Hama, S.Y., La Du, B.N., Faull, K.F., Fogelman, A.M. and Navab, M. (1995) Protective 
Effect of High Density Lipoprotein Associated Paraoxonase. Inhibition of the Biological Activity of Minimally Oxidized Low Density Lipoprotein. The Journal of Clinical Investigation, 96, 2882-2891. http://dx.doi.org/10.1172/JCI118359

[35] Van den Berg, R., Haenen, G.R.M.M., Van den Berg, H. and Bast, A. (2001) Transcription Factor NF- $\kappa$ B as a Potential Biomarker for Oxidative Stress. British Journal of Nutrition, 86, 121-127. http://dx.doi.org/10.1079/BJN2001340

[36] Naik, U.S., Gangadharan, C., Abbagani, K., Nagalla, B., Dasari, N. and Manna, S.K. (2011) A Study of Nuclear Transcription Factor-Kappa B in Childhood Autism. PLoS ONE, 6, e19488. http://dx.doi.org/10.1371/journal.pone.0019488

[37] Young, A.M., Campbell, E., Lynch, S., Suckling, J. and Powis, S.J. (2011) Aberrant NF-KappaB Expression in Autism Spectrum Condition: A Mechanism for Neuroinflammation. Frontiers in Psychiatry, 2, 27. http://dx.doi.org/10.3389/fpsyt.2011.00027

[38] Malik, M., Tauqeer, Z., Sheikh, A.M., Wen, G., Nagori, A., Yang, K., Brown, W.T. and Li, X. (2011) NF- $\kappa$ B Signaling in the Brain of Autistic Subjects. Mediators of Inflammation, 2011, Article ID: 785265. http://dx.doi.org/10.1155/2011/785265

[39] Halliwell, B. and Gutteridge, J.M.C. (1989) Free Radicals in Biology and Medicine. 2nd Edition, Clarendon Press, Oxford, 22-85.

[40] Sies, H. (1991) Role of Reactive Oxygen Species in Biological Processes. Klinische Wochenschrift, 69, 965-968. http://dx.doi.org/10.1007/BF01645140

[41] Halliwell, B. and Whiteman, M. (2004) Measuring Reactive Species and Oxidative Damage in Vivo and in Cell Culture: How Should You Do It and What Do the Results Mean? British Journal of Pharmacology, 142, 231-255. http://dx.doi.org/10.1038/sj.bjp.0705776

[42] Halliwell, B. and Cross, C.E. (1994) Oxygen-Derived Species: Their Relation to Human Disease and Environmental Stress. Environmental Health Perspectives, 102, 5-12. http://dx.doi.org/10.1289/ehp.94102s105

[43] Halliwell, B. (2007) Biochemistry of Oxidative Stress. Biochemical Society Transactions, 35, 1147-1150. http://dx.doi.org/10.1042/BST0351147

[44] Martin, H.L. and Teismann, P. (2009) Glutathione-A Review on Its Role and Significance in Parkinson's Disease. The FASEB Journal, 23, 3263-3272. http://dx.doi.org/10.1096/fj.08-125443

[45] Aoyama, K., Watabe, M. and Nakaki, T. (2008) Regulation of Neuronal Glutathione Synthesis. Journal of Pharmacological Sciences, 108, 227-238. http://dx.doi.org/10.1254/jphs.08R01CR

[46] González-Fraguela, M.E., Hung, M.-L.D., Vera, H., Maragoto, C., Noris, E., Blanco, L., Galvizu, R. and Robinson, M. (2013) Oxidative Stress Markers in Children with Autism Spectrum Disorders. British Journal of Medicine and Medical Research, 3, 307-317. http://dx.doi.org/10.9734/BJMMR/2013/2335

[47] Pecorelli, A., Leoncini, S., De Felice, C., Signorini, C., Cerrone, C., Valacchi, G., Ciccoli, L. and Hayek, J. (2013) Non-Protein-Bound Iron and 4-Hydroxynonenal Protein Adducts in Classic Autism. Brain \& Development, 35, $146-$ 154. http://dx.doi.org/10.1016/j.braindev.2012.03.011

[48] James, S.J., Rose, S., Melnyk, S., Jernigan, S., Blossom, S., Pavliv, O. and Gaylor, D.W. (2009) Cellular and Mitochondrial Glutathione Redox Imbalance in Lymphoblastoid Cells Derived from Children with Autism. The FASEB Joural, 23, 2374-2383. http://dx.doi.org/10.1096/fj.08-128926

[49] Chauhan, A., Audhya, T. and Chauhan, V. (2012) Brain Region-Specific Glutathione Redox Imbalance in Autism. Neurochemical Researchs, 37, 1681-1689. http://dx.doi.org/10.1007/s11064-012-0775-4

[50] Gu, F., Chauhan, V. and Chauhan, A. (2013) Impaired Synthesis and Antioxidant Defense of Glutathione in the Cerebellum of Autistic Subjects: Alterations in the Activities and Protein Expression of Glutathione-Related Enzymes. Free Radical Biology and Medicine, 65, 488-496. http://dx.doi.org/10.1016/j.freeradbiomed.2013.07.021

[51] Hauser, R.A., Lyons, K.E., McClain, T., Carter, S. and Perlmutter, D. (2009) Randomized, Double-Blind, Pilot Evaluation of Intravenous Glutathione in Parkinson’s Disease. Movement Disorders, 24, 979-983. http://dx.doi.org/10.1002/mds.22401

[52] Do, K.Q., Bovet, P. and Cuenod, M. (2004) Schizophrenia: Glutathione Deficit as a New Vulnerability Factor for Disconnectivity Syndrome. Schweizer Archiv für Neurologie, Neurochirurgie und Psychiatrie, 155, 375-385.

[53] Prior, R.L. and Cao, G. (1999) In Vivo Total Antioxidant Capacity: Comparison of Different Analytical Methods. Free Radical Biology and Medicine, 27, 1173-1181. http://dx.doi.org/10.1016/S0891-5849(99)00203-8

[54] Vassalle, C., Masini, S., Carpeggiani, C., L’Abbate, A., Boni, C. and Zucchelli, G.C. (2004) In Vivo Total Antioxidant Capacity: Comparison of Two Different Analytical Methods. Clinical Chemistry and Laboratory Medicine, 42, 84-89. http://dx.doi.org/10.1515/CCLM.2004.016 
[55] Ziyatdinova, G.K., Budnikov, H.C., Pogoreltzev, V.I. and Ganeev, T.S. (2006) The Application of Coulometry for Total Antioxidant Capacity Determination of Human Blood. Talanta, 68, 800-805. http://dx.doi.org/10.1016/j.talanta.2005.06.010

[56] Suresh, D.R., Annam, V., Pratibha, K. and Prasad, M.B.V. (2009) Total Antioxidant Capacity—A Novel Early BioChemical Marker of Oxidative Stress in HIV Infected Individuals. Journal of Biomedical Science, 16, 61. http://dx.doi.org/10.1186/1423-0127-16-61

[57] Papageorgiou, M., Stiakaki, E., Dimitriou, H., Malliaraki, N., Notas, G., Castanas, E. and Kalmanti, M. (2005) Cancer Chemotherapy Reduces Plasma Total Antioxidant Capacity in Children with Malignancies. Leukemia Research, 29, 11-16. http://dx.doi.org/10.1016/j.leukres.2004.04.017

[58] Abdel-Salam, O.M.E., Youness, E.R. and Hafez, H.F. (2011) The Antioxidant Status of the Plasma in Patients with Breast Cancer Undergoing Chemotherapy. Open Journal of Molecular and Integrative Physiology, 1, 29-35. http://dx.doi.org/10.4236/ojmip.2011.13005

[59] Primo-Parmo, S.L., Sorenson, R.C., Teiber, J. and La Du, B.N. (1996) The Human Serum Paraoxonase/Arylesterase Gene (PON1) Is One Member of a Multigene Family. Genomics, 33, 498-507. http://dx.doi.org/10.1006/geno.1996.0225

[60] Mackness, B., Quarck, R., Verreth, W., Mackness, M. and Holvoet, P. (2006) Human Paraoxonase-1 Overexpression Inhibits Atherosclerosis in a Mouse Model of Metabolic Syndrome. Arteriosclerosis, Thrombosis, and Vascular Biology, 26, 1545-1550. http://dx.doi.org/10.1161/01.ATV.0000222924.62641.aa

[61] Jamroz-Wisniewska, A., Beltowski, J., Stelmasiak, Z. and Bartosik-Psujek, H. (2009) Paraoxonase 1 Activity in Different Types of Multiple Sclerosis. Multiple Sclerosis Journal, 15, 399-402. http://dx.doi.org/10.1177/1352458508098371

[62] Kotan, V.O., Sarandol, E., Kirhan, E., Ozkaya, G. and Kirli, S. (2011) Effects of Long-Term Antidepressant Treatment on Oxidative Status in Major Depressive Disorder: A 24-Week Follow-Up Study. Progress in Neuro-Psychopharmacology and Biological Psychiatry, 35, 1284-1290. http://dx.doi.org/10.1016/j.pnpbp.2011.03.021

[63] Zengi, O., Karakas, A., Ergun, U., Senes, M., Inan, L. and Yucel, D. (2011) Urinary 8-Hydroxy-2'-Deoxyguanosine Level and Plasma Paraoxonase 1 Activity with Alzheimer’s Disease. Clinical Chemistry and Laboratory Medicine, 50, 529-534.

[64] Wehr, H., Bednarska-Makaruk, M., Graban, A., Lipczyńska-Łojkowska, W., Rodo, M., Bochyńska, A. and Ryglewicz, D. (2009) Paraoxonase Activity and Dementia. Journal of the Neurological Sciences, 283, 107-108. http://dx.doi.org/10.1016/j.jns.2009.02.317

[65] Gaita, L., Manzi, B., Sacco, R., Lintas, C., Altieri, L., Lombardi, F., Pawlowski, T.L., Redman, M., Craig, D.W., Huentelman, M.J., Ober-Reynolds, S., Brautigam, S., Melmed, R., Smith, C.J., Marsillach, J., Camps, J., Curatolo, P. and Persico, A.M. (2010) Decreased Serum Arylesterase Activity in Autism Spectrum Disorders. Psychiatry Research, 180, 105-113. http://dx.doi.org/10.1016/j.psychres.2010.04.010

[66] Aviram, M., Rosenblat, M., Billecke, S., Erogul, J., Sorenson, R., Bisgaier, C.L., Newton, R.S. and La Du, B. (1999) Human Serum Paraoxonase (PON 1) Is Inactivated by Oxidized Low Density Lipoprotein and Preserved by Antioxidants. Free Radical Biology and Medicine, 26, 892-904. http://dx.doi.org/10.1016/S0891-5849(98)00272-X

[67] Seres, I., Fulop, T., Paragh, G. and Khalil, A. (2008) Age-Related Alterations in PON1. In: Mackness, B., Mackness, M., Aviram, M. and Paragh, G., Eds., The Paraoxonases: Their Role in Disease Development and Xenobiotic Metabolism, Springer, Dordrecht, 199-206. 
Scientific Research Publishing (SCIRP) is one of the largest Open Access journal publishers. It is currently publishing more than 200 open access, online, peer-reviewed journals covering a wide range of academic disciplines. SCIRP serves the worldwide academic communities and contributes to the progress and application of science with its publication.

Other selected journals from SCIRP are listed as below. Submit your manuscript to us via either submit@scirp.org or Online Submission Portal.
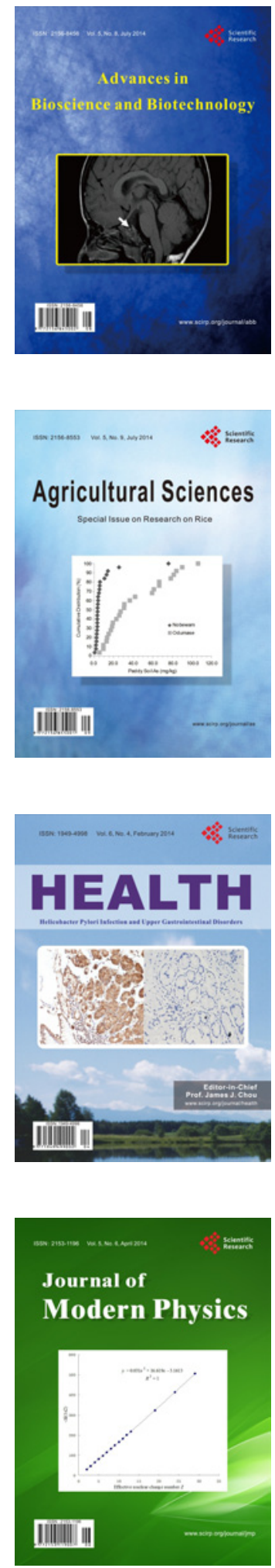
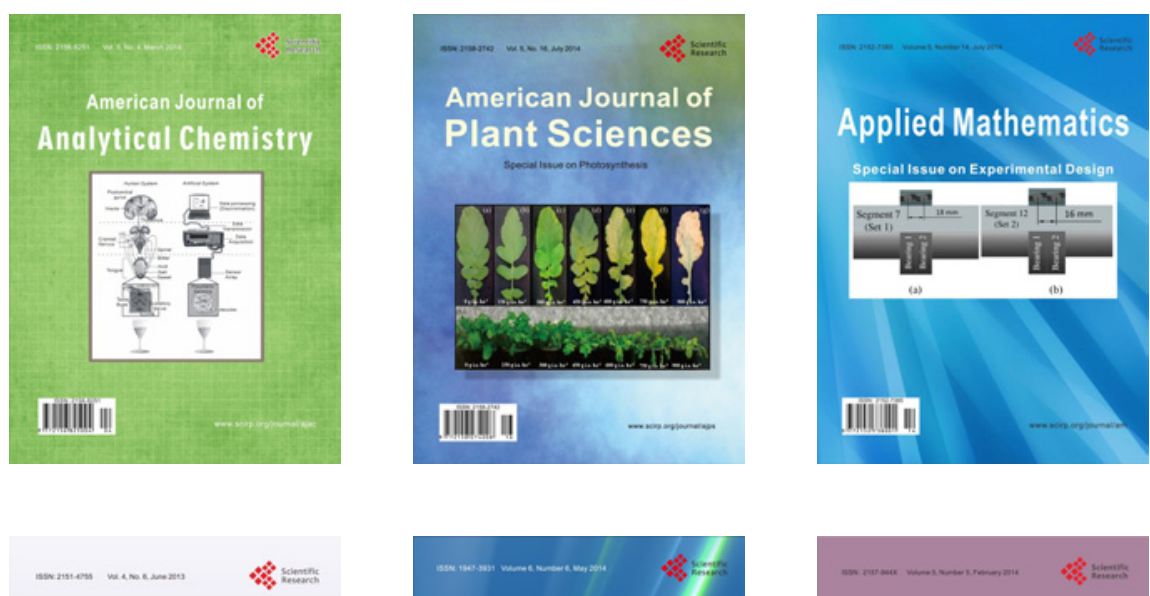

Creative Education
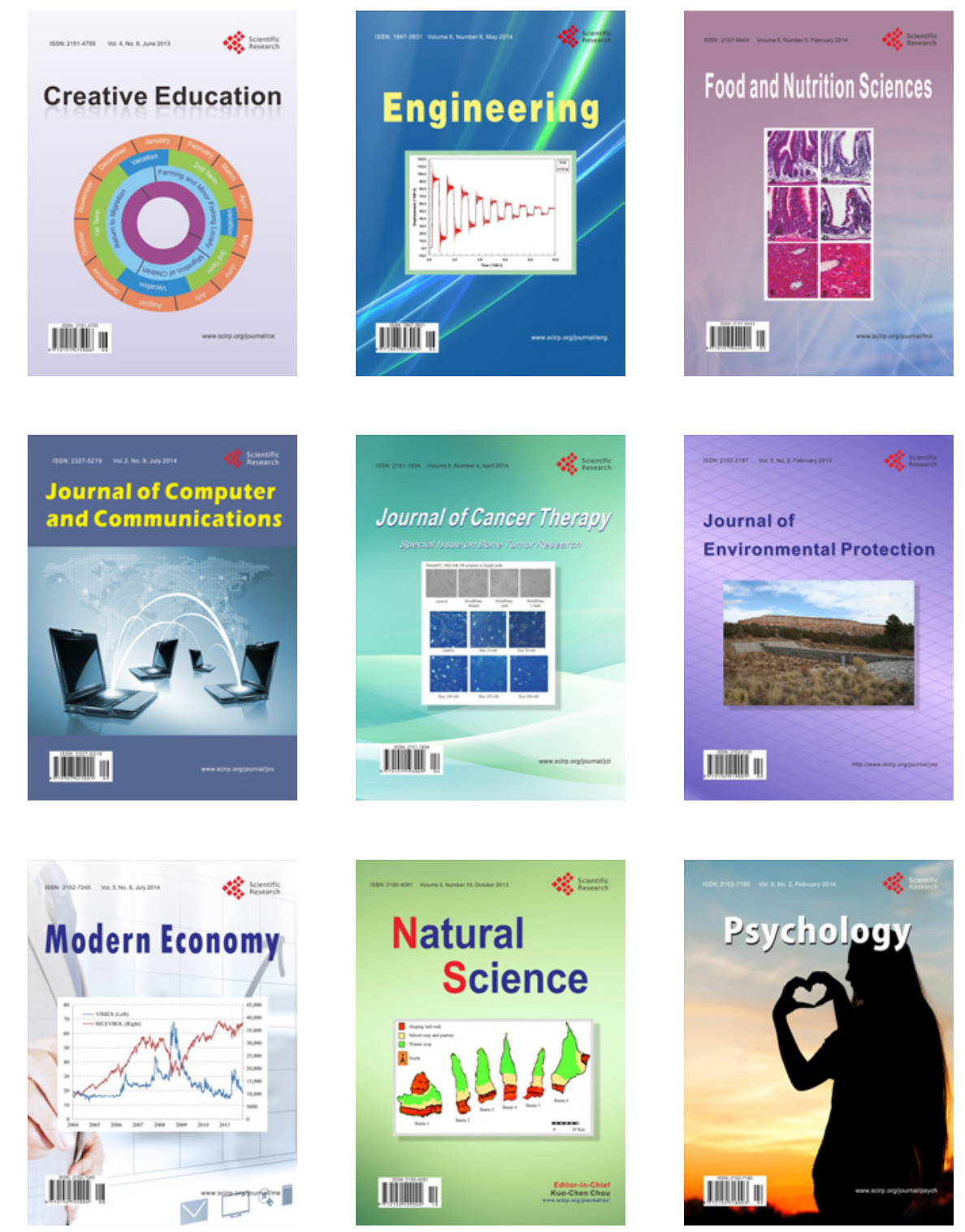